\title{
岩盤データベースを用いたNATM の事前設計のための物性值 \\ PROPERTIES FOR INITIAL DESIGN OF TUNNELS BY NATM USING ROCK MASS DATA-BASE SYSTEM
}

\author{
瀬崎満弘*・Ömer AYDAN**・市川康 明***・川本朓万**** \\ By Mitsuhiro SEZAKI, Ömer AYDAN, Yasuaki ICHIKAWA and Toshikazu KAWAMOTO
}

\begin{abstract}
The authors have developed a data-base system for the physical and mechanical properties of rock and rock mass especially for the initial design of tunnels by NATM. The features of this data-base system are described and the capabilities of the system have been demonstrated. By processing the all data of the system, it has been found out that the physical and mechanical properties of intact rock and rock mass can be predicted in terms of longitudinal elastic wave velocity $\left(V_{p}\right)$. On the basis of this finding emprical relations are suggested for the estimation of the properties of rock mass by using the insitu and field wave velocities and the properties of intact rock. Finally, a new proposal is made for the evaluation of properties of rock mass grade of the rock mass classification of Japan Roadway Association (JRA) in relation to the suggested formulas and wave velocities.
\end{abstract}

Keywords: rock properties, NATM, data-base system, longitudinal wave velocity

\section{1.はじめに}

今日の急速なコンピューターテクノロジーの発達に 伴って，データベースを構築するための技術が著しい進 展をみせ，大容量のハードディスクの低価格化と相まっ て，大型計算機によらなくてもかなりの規模のデータ ベースシステムの開発がパーソナルコンピューターを利 用することによって可能となった.こうした観点から， NATM に関するデータベースが関係する研究機関や企 業体で検討されるようになってきている ${ }^{1,2)}$.

近年, 山岳トンネルの掘削工法の主流となった NATM は, 地山のもつ耐力を積極的に利用しようとす る原理に基づくもので, 掘削後できる限り速やかに, 効 果的な支保を施工することが要求される.この NATM の導入によって, トンネルの調査・設計・施工が，計測 管理や地山解析といった合理的なシステムとして運用可 能となった。

* 正会員 工修 宮崎大学助手 工学部土木工学科 （８89-21＼cjkstart宮崎市学園木花台西 1-1）

** 正会員 工博 名古屋大学助手 工学部地盤工学教室 ( ₹464-01 名古屋市千種区不老町)

*** 正会員 工博 名古屋大学助教授 工学部地盤工学教室 (同上)

**** 正会員 工博 名古屋大学教授 工学部地盤工学教室 (同上)
現在, 川本らを中心とした委員会で,「NATM の設 計・施工におけるエキスパートシステムの開発」の研究 が進められている3 . このエキスパートシステムの開発 は，トンネルの事前設計を主体としたシステムの構築を 目指しており，標準支保パターンの決定，安定計算およ び有限要素法による解析が稼働中である. 本研究はこの エキスパートシステムを支援するための岩盤に関する データベースを開発することを目的とする.さらに，こ のデータベースを利用して NATM の事前設計のための 岩盤物性值を, 岩盤分類との関係を含めて検討するもの である。

\section{2. トンネルの岩盤分類}

一般に，NATM は，事前調査のデータをもとに事前 設計を行い，施工中の観察・計測に基づいて設計を修正 していく方法をとる.この事前に行われる地質調査では, 岩盤内の応力や岩盤の工学的特性を定量的に求めること は技術的, 経済的な制限から困難である.そのため, NATM の設計・施工では, 岩盤分類とその分類等級に 応じて作成した，標準支保パターンから支保を決定する 方法が取られることが多い.

岩盤構造物の設計, 施工においては種々の岩盤分類法 が提案されており，使用の対象により，またそれを使用 
する時期によって，分類因子の選び方は多岐にわたって いる4).

トンネルに対する岩盤分類は, 使用する時期によって 2 種類に分けられる. 1つは, 事前設計および積算のた めに用いられるものであり, 他方は, 施工中の実際の切 羽の評価のために用いられる. 前者は工事発注のための 分類であり，わが国の主なものに道路公団 ${ }^{5)}, \mathrm{JR}^{6)}$, 農 水省》 の諸分類がある. 事前調査の結果から得られる岩 種, 地山の縦弾性波速度, ボーリングコアの状態などが 主な分類因子となっている. 後者は, ヨーロッパ系に属 する岩盤分類であり，施工中でなければ実際の分類因子 が得られないが, 近年では RSR 法年, RMR 法 ${ }^{91}, Q$ シ ステム ${ }^{10)}$ の手法のように, 各分類因子の評点から総合 点を求め, その総合点を何段階かに分類し, NATMの 支保の設計に適用する岩盤分類が提案されている. わが 国では, 清水らのファジー理論を用いた分類法 ${ }^{11)}$, 岩田 らの 2 軸岩盤分類法 ${ }^{12)}$, 数量化理論を使った樗木らの岩 盤分類法 ${ }^{13)}$ が提案されている. 主な分類因子としては, 岩盤の強度 (地質状況) に加えて, 切羽の観察から得ら れる節理面あるいは不連続面の状況, 湧水の状況などが 挙げられる.

\section{3. 岩盤データベース}

\section{（1）データベースの内容}

岩盤データベースの項目の一覧を表一1 に示す．合計 22 の項目がある。主にトンネルとダム基礎の地質調查 を対象にしたデータベースである. トンネルの 1 断面で 採取されたコアの室内岩石試験より得られる物性に対し

表一1 データベースの項目

\begin{tabular}{|c|c|c|}
\hline $\begin{array}{l}\text { 項 目 } \\
\text { 分 類 }\end{array}$ & $\begin{array}{l}\text { 番 } \\
\text { 号 } \\
\end{array}$ & 内 \\
\hline 一 般 & 1 & 工 事 名 \\
\hline 項 目 & 2 & 都道府県名 \\
\hline 地 質 & 3 & 地質 時 代 \\
\hline \multirow[t]{2}{*}{ 条 件 } & 4 & 地 層 名 \\
\hline & 5 & 岩石名 \\
\hline 設 計 & 6 & 地山分類 の方法 \\
\hline \multirow[t]{2}{*}{ 条 件 } & 7 & 岩 種 \\
\hline & 8 & 地山等 級 \\
\hline \multirow[t]{2}{*}{ 岩 } & 9 & 縦弾性波速度， $\mathrm{km} / \mathrm{s}$ \\
\hline & 10 & 横弾性波速度， $\mathrm{km} / \mathrm{s}$ \\
\hline \multirow[t]{2}{*}{ 石 } & 11 & 密度, $t / m^{3}$ \\
\hline & 12 & 一軸圧縮強度， $\mathrm{kg} \mathrm{f} / \mathrm{cm}^{2}$ \\
\hline \multirow[t]{2}{*}{ 物 } & 13 & 静的弾性係数, $\mathrm{kg} \mathrm{f} / \mathrm{cm}^{2}$ \\
\hline & 14 & 静的ポアソン比 \\
\hline \multirow[t]{2}{*}{ 性 } & 15 & 内 部 摩 擦 角，・ \\
\hline & 16 & 粘着力, $\mathrm{kgf} / \mathrm{cm}^{2}$ \\
\hline 岩 & 17 & 縦弾性波速度， $\mathrm{km} / \mathrm{s}$ \\
\hline 盤 & 18 & 横弾性波速度， $\mathrm{km} / \mathrm{s}$ \\
\hline 物 & 19 & $\mathrm{~N}$ 值 \\
\hline 性 & 20 & $\mathrm{R} Q \mathrm{Q}$ 值 \\
\hline その & 21 & 参考文献 \\
\hline 他 & 22 & 発 刊 年 月 \\
\hline
\end{tabular}

ては岩石物性とし, 原位置での試験から得られる物性に 対しては岩盤物性と分類した。またその断面での設計条 件が既知の場合，地山分類の方法（道路公団, JR, 電 研分類など), 岩種（道路公団では a, b , c , d 1, d 2, e, 国鉄では $\mathrm{A}, \mathrm{B}, \mathrm{C}, \mathrm{E}, \mathrm{F}, \mathrm{G})$ ，地山等級を入力するも のである.

データベースを構成する基礎データの収集の方法を示 すと，(1)施工会社の担当者にアンケートに答えてもらう 形で収集したデー夕，(2)既往文献に発表された岩石試験 結果，主なものは文献に示した ${ }^{14), 157}$, (3)主に道路と鉄道 トンネルに関する工事報告書に記載されている地質調査 結果, の 3 通りで, デー夕数としては約 2500 である.

（2）データベースシステムの概要

このシステムは，簡易リレーショナル・データベース 言語 “日本語 dBASE III”で作成した. システム構成を 図一1に示す。

メインプログラムは, データの入力, 追加, 更新, 削 除を行う. 入力したデータの検索を行う条件検索プログ ラムは, 論理和, 論理積による検索ができ, 数值デー夕 之文字デー夕の複合検索も可能である。検索してきた結 果は, ディスプレイまたはプリンターに出力される. 置 き換えプログラムは，コードで入力されたデータをそれ に対応する日本語に置き換えるものである，このシステ ムでは, 入力, 検索時の日本語入力の手間を省くため, 入力データが固定している項目に対しては，コードで入 力し, 印刷あるいは検索時出力の際はそれに対応する日 本語で出力するものである. 並び替えプログラムは, 特 定の項目のデー夕を昇順に並び替えるもので, 数值デー 夕と文字データに対して行える.印刷プログラムは, デー タベースのプリンターへの出力を制御するもので, 決め られたフォーマットで出力する方法と, データベースの 中の必要な項目だけを, 希望する順序で出力する方法が 選択できる。

今まで述べたプログラムは, dBASE III で機能するも のであるが，二次元相関図と頻度分布図を描くプログラ ムを N 88-BASIC で作成した. dBASE IIIの必要な項目

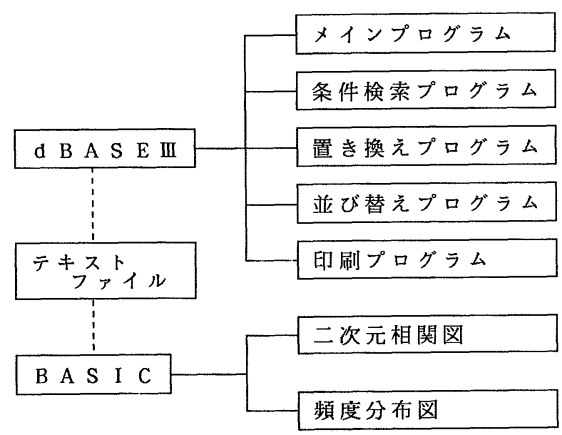

図一1 システムの構成 
のデータをアスキーコードでテキストファイルに書き込 み, これを N 88-BASIC で読んで図形を描くもので, 条件検索プログラムと同様に, 条件に合致したデータだ けを選べる.

\section{4. データベースを用いた岩盤物性}

\section{（1）岩石物性}

岩石または岩盤の物理的性質や力学的性質を間接的に 知るために, 弾性波速度を用いる方法は, 一般に広く利 用されており，これまでに弾性波速度とこれらの物理定 数および力学定数との相関関係が検討されてきてい $3^{16), 17)}$.

岩盤データベースの岩石物性について検討する場合で も，弾性波速度と他の物性との関係を考えてみることに する. 図一2に，横軸に岩石の弾性波速度，縦軸にそれ ぞれ密度, 一軸圧縮強度, 静的弾性係数および静的ポア ソン比をとり，これら 4 つの物性值と弾性波速度の相関 関係を示す. 以下, 煩雑さを避けるため, 静的弾性係数 は弾性係数と, 静的ポアソン比はポアソン比と書くこと にする. 岩石の種類は, 全デー夕を対象にしたものと, 堆積岩, 深成岩, 火山岩から代表的なものとして, 砂岩, 花崗岩, 安山岩の 3 つを選んだ. 図中の実線は, 最小 2 乗法による近似を示すもので，密度，一軸圧縮強度およ び弾性係数は指数関数で, ポアソン比は一次式で近似し てある.また，表一2に，得られた近似式と相関係数を 示してある.ここで, 弾性係数については, データベー スに収容されているデー夕の試験方法が一定でなく，值 には接線弾性係数, 割線弾性係数または他の方法による 弾性係数が混在しているため，ここでは一括して岩石の 弾性係数として取り扱う.

等方弾性体の理論によれば，半無限弾性体を伝わる縦 弾性波速度 $\left(V_{p}\right)$ と, 他の物性値間には次式の関係が あることが知られている。

$$
\begin{aligned}
& V_{p}=\sqrt{\frac{E(1-\nu)}{\rho(1+\nu)(1-2 \nu)}} \cdots \\
& E=\rho V_{\rho}^{2} \frac{(1+\nu)(1-2 \nu)}{(1-\nu)}
\end{aligned}
$$

ここで, $V_{p}$ は縦弾性波速度, $E$ は動的弾性係数, $\rho$ は
密度, レは動的ポアソン比である.

まず，弾性波速度と密度の関係について考察する．図 から明らかなように，全体的には密度は速度の増加とと もに増大する傾向にある．特に，堆積岩である砂岩はこ の傾向が著しく，速度と密度の相関係数は高い．安山岩 も砂岩と同様な傾向を示すが，速度が高く，密度が大き い方へデータが集中してくる．この砂岩と安山岩の挙動 は，速度が岩石の固結度とよい相関性をもつことを示し ている. 一方, 深成岩である花崗岩は速度の増大にもか かわらず, 密度は 2.6 付近に集中しており, 他の岩石之 異なった特徴を示す．花崗岩については後で考察する.

弾性波速度と一軸圧縮強度の関係については, 全デー 夕の図からわかるように相当にばらついたものになって いる．特に，速度の高いところでこの傾向が著しい．し かし，各岩石ごとにみれば，砂岩と花崗岩は比較的よい 相関を示す.しかし，安山岩は速度の高いところでの強 度のばらつきが大きく相関係数は低い，大久保，寺崎 ${ }^{16)}$ は，両者の関係を次の実験式で近似している.

$$
q_{u}=10 V_{p}^{3}
$$

表一2 からわかるように，全デー夕に対しては非常に似 た結果を得たが，花崗岩については，強度は速度の約 2 乗に比例するという他の岩石と異なった結果を得た.

弾性波速度と弾性係数の関係は，一軸圧縮強度と同様 に相当ばらついたものとなっているが，相関係数は弾性 係数の方が比較的に高い. 全データ，砂岩それに安山岩 に対して, 弾性係数は速度の約 3 乗に比例する結果を得 た. 前出の大久保，寺崎も全く同様の結論を得ている. ここでも花崗岩は異なった挙動を示し, 一軸強度とほぼ 同じ，約 2 乗に比例する結果を得た. 理論的には式 (2) に示すように，弾性係数は速度の約 2 乗に比例すること になる.ただしこの弾性係数は, 動的弾性係数を表わす ものである.この理論と実験結果との違いは，動的弾性 係数と静的弾性係数との関係が非線形であるためと考え られる.つまり，動的弾性係数と静的弾性係数との関係 については, 砂岩と安山岩は非線形性が大きく, 花崗岩 はほぼ線形に近いことがいえる。ここでは他の岩石の結 果を示していないが, 堆積岩, 火山岩, 深成岩の全体に ついて同様のことがいえる.

\section{表一2 弾性波速度と各物性值間の近似式と相関係数}

\begin{tabular}{|c|l|l|l|l|}
\hline & \multicolumn{1}{|c|}{ 全データ } & \multicolumn{1}{c|}{ 砂岩 } & \multicolumn{1}{c|}{ 花崗岩 } & \multicolumn{1}{c|}{ 安山岩 } \\
\hline 密度 & $\rho=1.8 V_{p}^{0.22}$ & $\rho=1.8 V_{p}^{0.23}$ & $\rho=2.4 V_{p}^{0.04}$ & $\rho=1.7 V_{p}^{0.26}$ \\
$\left(\mathrm{~g} / \mathrm{cm}^{3}\right)$ & $r=0.76$ & $r=0.85$ & $r=0.63$ & $r=0.77$ \\
\hline 一軸圧縮強度 & $q_{u}=9.8 V_{p}^{2.7}$ & $q_{u}=14.0 V_{p}^{2.6}$ & $q_{u}=41.0 V_{p}^{2.1}$ & $q_{u}=8.5 V_{p}^{2.9}$ \\
$\left(\mathrm{kgf} / \mathrm{cm}^{2}\right)$ & $r=0.61$ & $r=0.67$ & $r=0.81$ & $r=0.29$ \\
\hline 弾性係数 & $E=2048 V_{p}^{3.0}$ & $E=2368 V_{p}^{2.9}$ & $E=10000 V_{p}^{2.1}$ & $E=2288 V_{p}^{2.9}$ \\
$\left(\mathrm{kgf} / \mathrm{cm}^{2}\right)$ & $r=0.77$ & $r=0.74$ & $r=0.63$ & $r=0.64$ \\
\hline ポアソン比 & $\nu=0.36-0.02 V_{p}$ & $\nu=0.37-0.03 V_{p}$ & $\nu=0.32-0.01 V_{p}$ & $\nu=0.39-0.03 V_{p}$ \\
& $r=0.55$ & $r=0.60$ & $r=0.34$ & $r=0.52$ \\
\hline
\end{tabular}



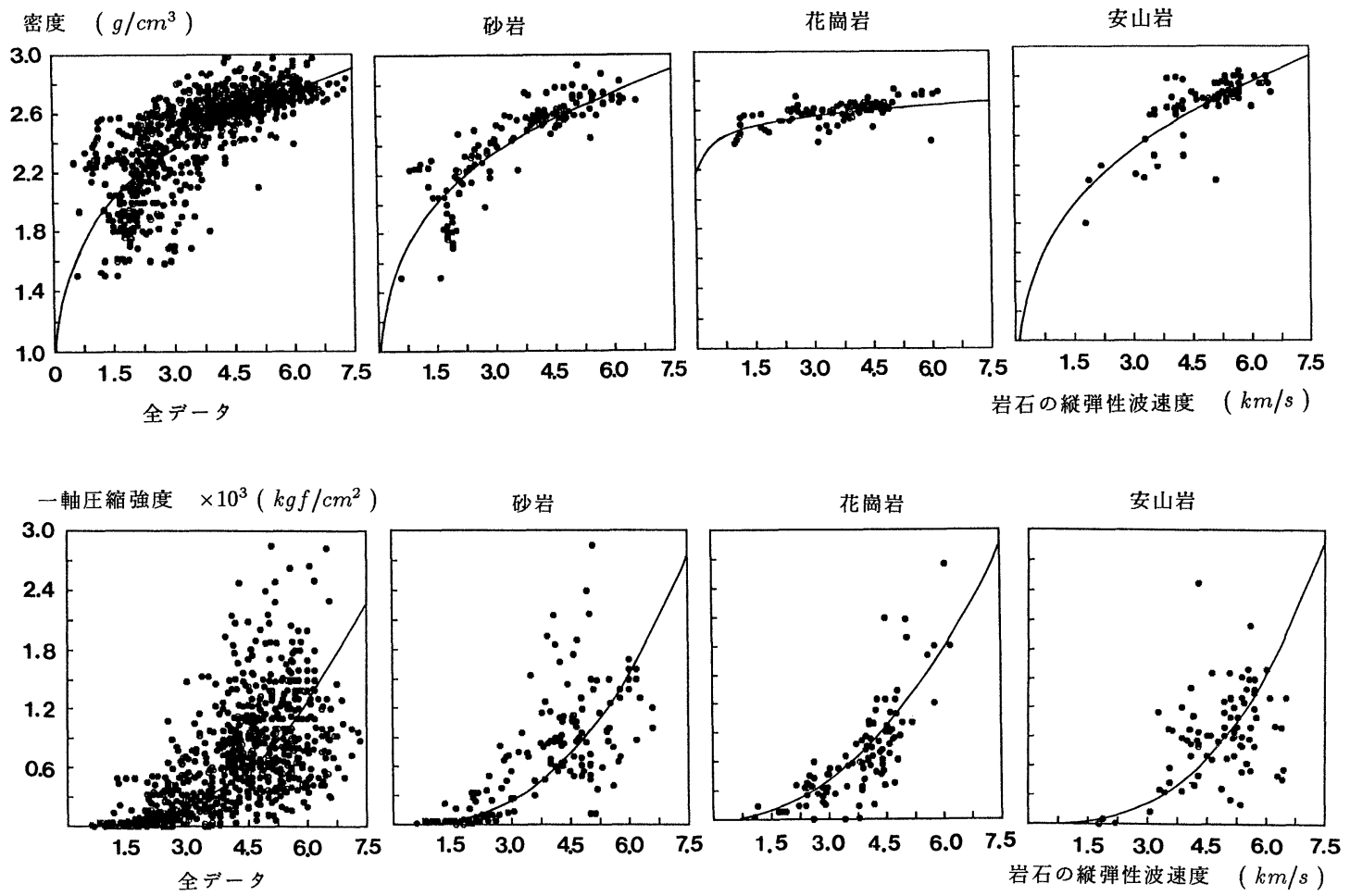

弾性係数 $\times 10^{3}\left(\mathrm{kgf} / \mathrm{cm}^{2}\right)$

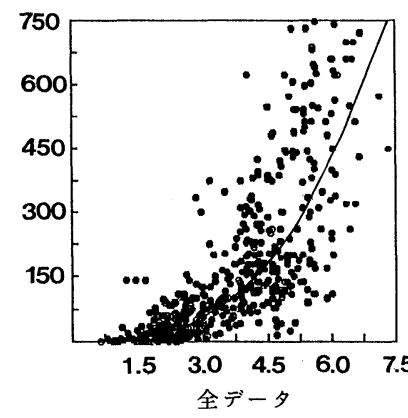

砂岩

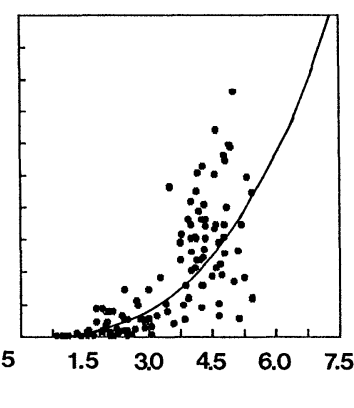

安山岩
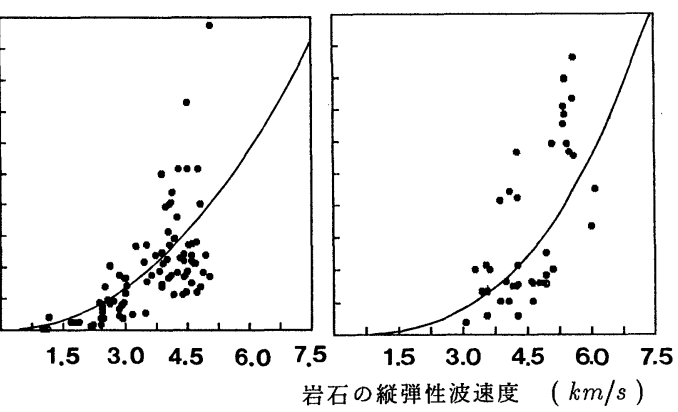

ポアソン比

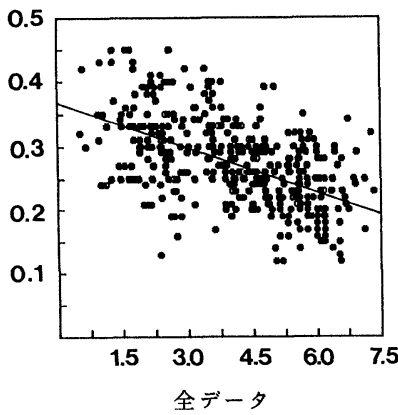

砂岩

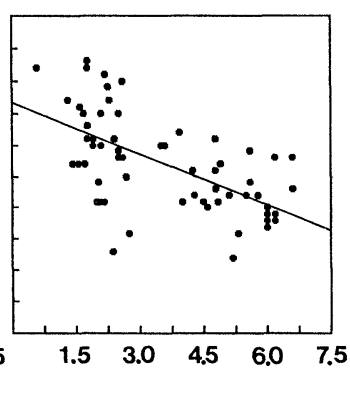

花崗岩

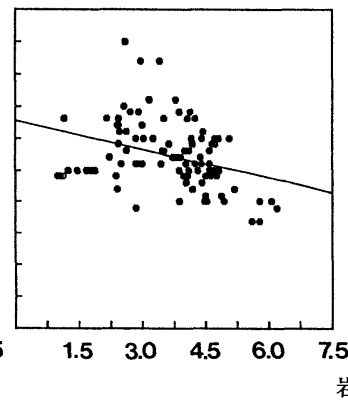

安山岩

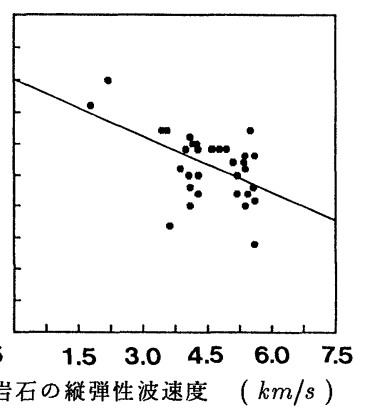

図一2 岩石の縦弾性波速度と各物性値間の関係 
弾性波速度とポアソン比との関係については, 図から わかるように，相当ばらついたものになっている．最小 2 乗法の近似では, 右下がりの負の関係を得ることがで きるが，相関係数はあまり高くない.

ここで, 花崗岩について考えてみる. 花崗岩は弾性波 速度自体があまり大きくならず, さらに, 他の岩石と比 ベて, 同じ弾性波速度では, 一軸圧縮強度と弾性係数の 值は小さい。このことは, 造岩鉱物が複雑なうえに, 結 晶構造が発達しているために, 結晶間に微細なクラック が存在することが原因と思われる.

\section{5. 岩盤物性值と岩石物性值について}

\section{（1）岩盤と岩石の弾性波速度}

トンネルなど地盤を数学的に解析しようとするとき, 当然必要となってくる物性値は, 岩盤についてのもので ある. 岩盤の強度および弾性係数は, 節理, 亀裂, 破砕 帯等の弱面の存在亡, 空隙の存在, 吸水状態それに風化 の影響を強く受けることはよく知られている。一方, 弾 性波速度は式（1）に示されるように, 弾性係数, ポア ソン比それに密度の関数であるが, これらの物性は前述 の影響のほかに外的条件としての温度, 圧力の影響を受 ける。

岩石試験から得られる物性值から, 岩盤の物性值を推 定しようとするときに広く利用されるパラメーターに, 割れ目指数と岩目係数がある. 割れ目指数を式 (4) に 示すが, 岩盤内の弾性波速度とその岩盤から採取した亀 裂を含まない岩石試料の弾性波速度の比を取ったもので ある.この割れ目指数が，岩盤中に存在する弱面による 弾性波速度の低下率を示すといわれ，この值が小さけれ ば小さいほよ゙岩盤中にクラック等の弱面が多く存在する ことになる. 岩目係数を式（5）に示すが, 割れ目指数 を 2 乗したものである. 岩盤の弾性係数はこの岩目係数 を，供試体の試験から得られる弾性係数に掛けることで 推定できる.この 2 乗は式（2）の弾性係数が弾性波速 度の 2 乗に比例することによるものである．しかしなが ら，4.で述べたように，花崗岩などの深成岩を除いては このような関係にはならない。

$$
\begin{aligned}
& K=\frac{V_{p m}}{V_{p r}} \cdots \\
& f=\left(\frac{V_{p m}}{V_{p r}}\right)^{2} .
\end{aligned}
$$

ここで, $K$ は割れ目指数, $f$ は岩目係数, $V_{p m}$ は岩盤 の縦弾性波速度, $V_{p r}$ は岩石の縦弾性波速度である

このデータベースシステムに収められている全岩石に ついて,岩石と岩盤の弾性波速度の関係をとったものを， 図一3に示す．図からわかるように，両者は比較的に相 関係数が高く, 一次式で近似すると 0.86 の傾きを得た.

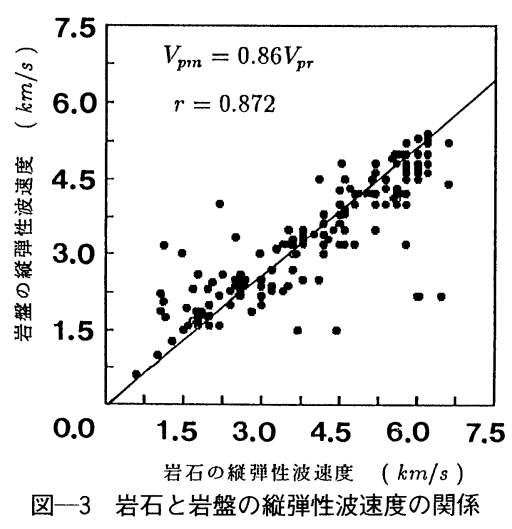

この值が式 (4) に示す割れ目係数の平均的な値となる. 岩石の弾性波速度の值が低いところでは, 割れ目係数 $K$ が 1 より大きくなるものがある.つまり, 岩盤の弾 性波速度が岩石のより大きくなることで，このことは， 弾性波速度の低いところでは岩盤に弱面が存在するにし てもほとんど影響せず，むしろ土被りによる拘束圧や水 による影響が大きいと思われる. 弾性波速度の高いとこ ろでは割れ目係数が 1 より小さくなり, 岩盤中に存在す る弱面によって岩盤の弾性波速度が低下したことを示し ている.

\section{（2）岩盤の弾性係数と一軸圧縮強度}

表一2に示したように, 全データに対して, 岩石の弾 性係数は岩石の弾性波速度の 3.0 乗に比例し, 同じく岩 石の一軸圧縮強度は岩石の弾性波速度の 2.7 乗に比例す る. 岩盤においても同様の関係が成り立つものと仮定す る。つまり，岩盤の弾性係数は岩盤の弾性波速度の 3.0 乗に比例し, 岩盤の一軸圧縮強度は岩盤の弾性波速度の 2.7 乗に比例するものとする.この考え方に基ゔくと, 岩盤の弾性係数と一軸圧縮強度は割れ目係数 $K$ を用い, 次式で求めることができる.

$$
\begin{aligned}
& E_{m}=K^{3.0} E_{r} . \\
& q_{u m}=K^{2.7} q_{u r}
\end{aligned}
$$

ここで, $E_{m}$ は岩盤の弾性係数, $E_{r}$ は岩石の弾性係数,

\begin{tabular}{|c|c|c|}
\hline \multirow[t]{2}{*}{ a } & 変成岩 & $\begin{array}{l}\text { 千枚岩, 石墨片岩, 珪質石墨片岩, 石英片岩, } \\
\text { 緑色片岩, 片麻岩, 蛇紋岩, ホルンフェルス等 }\end{array}$ \\
\hline & 深成岩 & 斑れい岩，かんらん岩等 \\
\hline $\mathrm{b}$ & $\begin{array}{l}\text { 古生層および } \\
\text { 中生層 }\end{array}$ & $\begin{array}{l}\text { 粘板岩, 砂岩および碰岩, 硬砂岩, 石灰岩, } \\
\text { 珪岩, 輝緑凝灰岩等 }\end{array}$ \\
\hline \multirow[t]{3}{*}{$\mathrm{c}$} & 火山岩 & 石英粗面岩, 安山岩, 玄武岩等 \\
\hline & 脈 岩 & 花而斑岩, 石英斑岩, ひん岩, 輝緑岩等 \\
\hline & 樑成岩 & 花崗岩, 閃緑岩等 \\
\hline $\mathrm{d}$ & $\begin{array}{l}\text { 第三紀層および } \\
\text { 下部洪積層 }\end{array}$ & $\begin{array}{l}\text { 泥岩, 頁岩, 珪質頁岩, 砂岩および磁岩, } \\
\text { 凝灰岩, 凝灰角磁岩, 集塊岩等 }\end{array}$ \\
\hline \multirow[t]{2}{*}{$\mathrm{e}$} & 上部洪積層 & ロームおよび粘土, 火山砕屏物 \\
\hline & 沖積層 & 崖錐, 表土等 \\
\hline
\end{tabular}
$q_{u m}$ は岩盤の一軸圧縮強度, $q_{u r}$ は岩石の一軸圧縮強度 である。

表一3 道路公団の岩盤分類の岩種 
表一4 道路公団岩種と各物性值間の近似式と相関係数

\begin{tabular}{|c|l|l|l|l|}
\hline & \multicolumn{1}{|c|}{ 岩種 $\mathrm{a}$} & \multicolumn{1}{c|}{ 岩種 $\mathrm{b}$} & \multicolumn{1}{c|}{ 岩種 $\mathrm{c}$} & \multicolumn{1}{c|}{ 岩種 $\mathrm{d}$} \\
\hline 密度 & $\rho=2.2 V_{p}^{0.12}$ & $\rho=2.4 V_{p}^{0.07}$ & $\rho=2.3 V_{p}^{0.09}$ & $\rho=1.8 V_{p}^{0.17}$ \\
$\left(\mathrm{~g} / \mathrm{cm}^{3}\right)$ & $r=0.79$ & $r=0.43$ & $r=0.52$ & $r=0.51$ \\
\hline 一軸圧縮強度 & $q_{u}=4.5 V_{p}^{3.0}$ & $q_{u}=15.0 V_{p}^{2.7}$ & $\begin{array}{l}q_{u}=40.0 V_{p}^{2.1} \\
r=0.54\end{array}$ & $\begin{array}{l}q_{u}=7.8 V_{p}^{3.1} \\
\left(\mathrm{kgf} / \mathrm{cm}^{2}\right)\end{array}$ \\
\hline 弾性係数 & $E=0.40$ & $r=0.20$ & $r=0.79$ \\
$\left(\mathrm{kgf} / \mathrm{cm}^{2}\right)$ & $r=0.77$ & $E=10000 V_{p}^{2.3}$ & $E=9000 V_{p}^{2.2}$ & $E=2448 V_{p}^{2.6}$ \\
\hline ポアソン比 & $\nu=0.36-0.02 V_{p}$ & $\nu=0.28-0.01 V_{p}$ & $\nu=0.30-0.01 V_{p}$ & $\nu=0.33-0.02 V_{p}$ \\
& $r=0.56$ & $r=0.21$ & $r=0.22$ & $r=0.27$ \\
\hline
\end{tabular}

ポアソン比と密度に関しては, 岩盤中でも岩石と変わ らないと考え，同じ值を用いることとする.

\section{6. 道路公団の岩盤分類と物性值}

トンネルの設計に必要とされる物性值が，岩盤分類と 関連づけられていれば，岩盤分類の客観性あるいは岩盤 の評価において非常に有意義であろう。菊地ら ${ }^{18)}$ は田中 による方法 (電研分類) を進展させた新しい岩盤分類方 法を提案し, その分類と弾性係数, 粘着力, 内部摩擦角 等の物理定数を関連づけ，その相関性を考察している。 著者らは道路公団の岩盤分類について同様のことを試み た。

道路公団の岩盤分類の岩種を表一3に示す．この岩種 ごとに，4. で求めたものと同様の相関図を作成した。 そ の結果を図一 4 に示す. 図中の実線は最小二乗法で求め た近似曲線を表わしており，その近似式と相関係数を表 一4に示してある.ここで，岩種 $\mathrm{d}$ については一軸圧縮

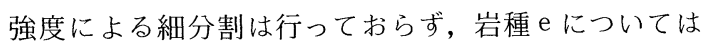
データの数が少ないため, 示すことができなかった.

岩種 $\mathrm{a}$ は, 変成岩と塩基性深成岩である. 変成岩とし ては, 片麻岩, 片岩類, 蛇紋岩のデー夕が多く, 深成岩 としては斑れい岩のデータがわずかにあるだけである. デー夕は, 弾性波速度の值が低いところには比較的に少 なく, 速度の值が $3.0 \mathrm{~km} / \mathrm{s}$ 以上のところに多い. 密度, 弾性係数およびポアソン比の相関係数は高いが, 一軸圧 縮強度は低い. 変成岩のなかには, ある方向への異方性 が非常に強いものがあり, 載荷方向によって值が相当に ばらつくことが知られている. 密度の相関がよく, 一軸 圧縮強度の相関がよくないのは, この理由によるもので あろう。

岩種 b は, 古生層および中生層の堆積岩である.デー 夕としては, 粘板岩, 硬砂岩, 石灰岩が多い, 密度が $2.6 \mathrm{~g} / \mathrm{cm}^{3}$ 付近に集中しており, 固結度は高い. そのた め, 弾性波速度の值も高く, $2.5 \mathrm{~km} / \mathrm{s}$ 以上に集中して いる. 反面, 速度に対する一軸圧縮強度, 弾性係数, ポ アソン比のばらつきが大きく, 相関係数はすべての岩種 の中で一番低い. 古い堆積岩のため固結度が高いが, 岩 石のなかに存在する微細なクラックが影響してばらつき
が大きいと考えられる.

岩種 c は, 火山岩, 脈岩および酸性深成岩である. 火 山岩では安山岩のデータが圧倒的に多く, 石英粗面岩が わずかにある．脈岩のデー夕はほとんどない，深成岩で は花崗岩のデー夕が相当数あり, 閃緑岩はそれほど多く ない. 4.で述べた花崗岩と安山岩を足したような形とな り, 全体的には岩種 $\mathrm{a}$ と似たような特徵をもつ.しかし, 岩種 $\mathrm{a}$ に比べて弾性波速度の值が低くなり, 密度, 弾性 係数およびポアソン比ともばらつきが大きくなる.一軸 圧縮強度および弾性係数とも，弾性波速度に対して余り 大きくならず，どちらかといえば花崗岩に近い特徵をも つ.

岩種 $\mathrm{d}$ は,第三紀層および下部洪積層の堆積岩である. データとしては, 砂岩と泥岩が圧倒的に多く, それに凝 灰岩が続く. 特徴として, 密度が他の岩種より大部小さ くなり，弾性波速度の值が $4.5 \mathrm{~km} / \mathrm{s}$ 以下に集中してく る. 一軸圧縮強度と弾性係数の值が, 同様に小さくなる. その分ばらつきが小さくなるため相関係数は高くなる. 特に, 一軸圧縮強度の相関係数が他の岩種と比べて最も 高くなる.

表一5に, 道路公団分類の岩種について, 弾性波速度 に対しての物性值を示した. この值は前述の各岩種ごと の近似式に弾性波速度を代入して求めたもので, その岩 種での岩石の物性值の平均と考えてよい. A から D II までの記号は, 道路公団の地山等級に相当するものであ るが，この記号は岩石の弾性波速度で区分してある．道 路公団の地山等級は, 岩盤の弾性波速度で区分されるた め, 実際の地山等級とは異なる. さらに, 実際の分類で は岩種, 弾性波速度のほかに地山強度比, ボーリングコ アの状態，地質状態などの判断材料が加わるため，この ように簡単にはいかない.

トンネルの設計においては, 岩盤分類を行うために通 常，岩盤の弾性波速度の調査が必要となる。トンネルの 数值解析を行うとするとき，この岩盤の弾性波速度を用 いて，岩盤の物性值を推定することができる．数值解析 を行おうとする断面の数か所で, 亀裂のない岩石の弾性 波速度を測定する。この值を平均したものを，断面での 岩石の弾性波速度とする。この岩石の弾性波速度と調査 

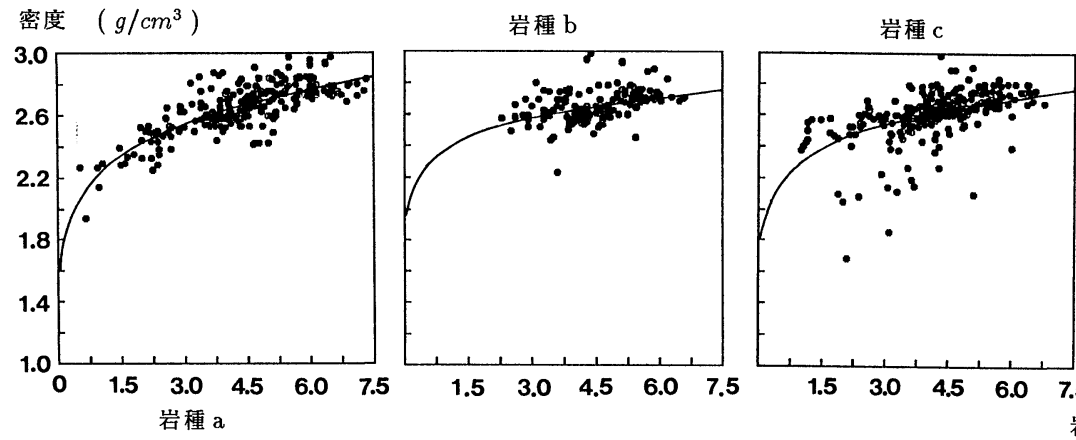

岩種 $\mathrm{d}$

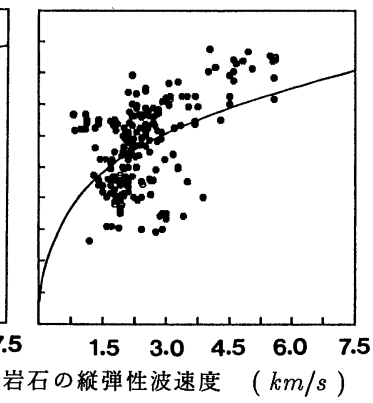

一軸圧縮強度 $\times 10^{3}\left(\mathrm{kgf} / \mathrm{cm}^{2}\right)$

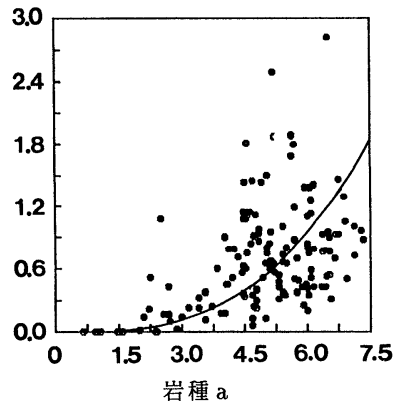

岩種 b

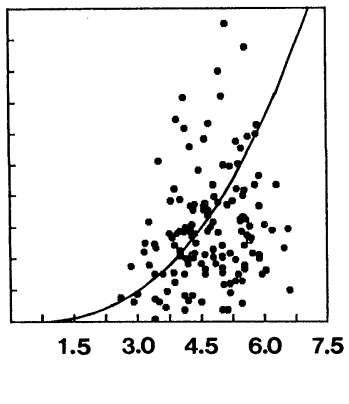

岩種 c

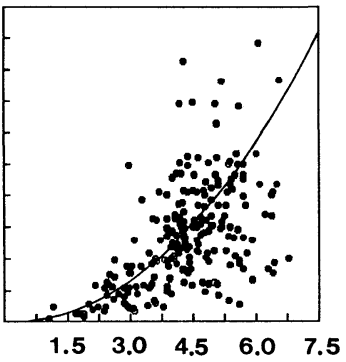

岩種 d

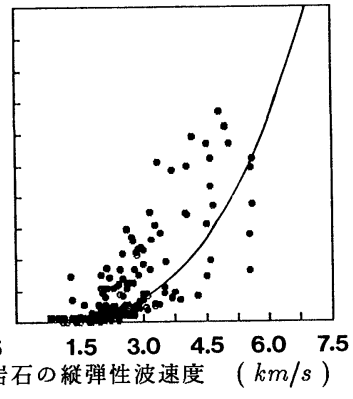

弾性係数 $\times 10^{3}\left(\mathrm{kgf} / \mathrm{cm}^{2}\right)$

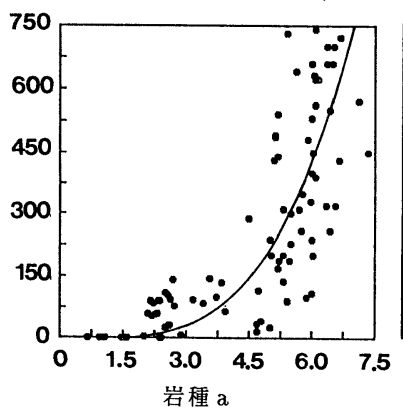

岩種 b

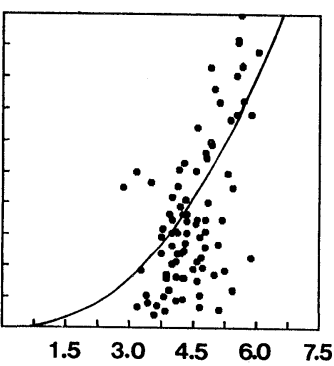

岩種 c

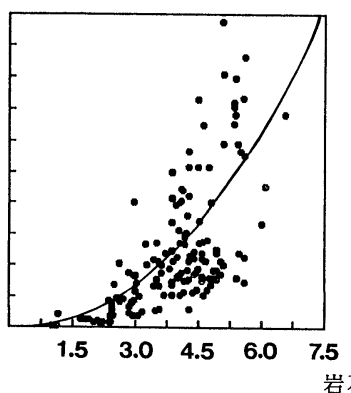

岩種 $d$

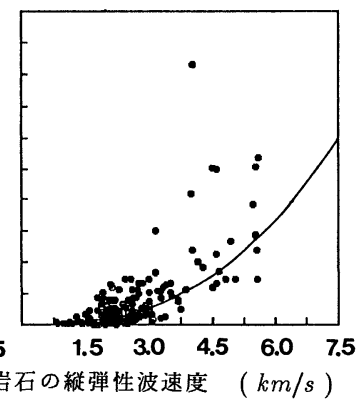

ポアソン比

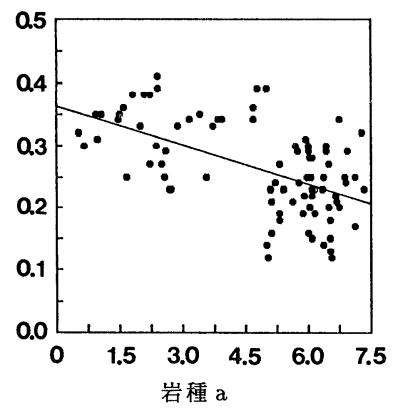

岩種 b

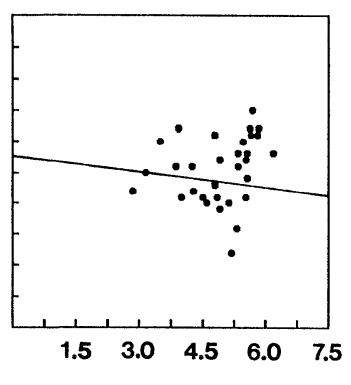

岩種 c

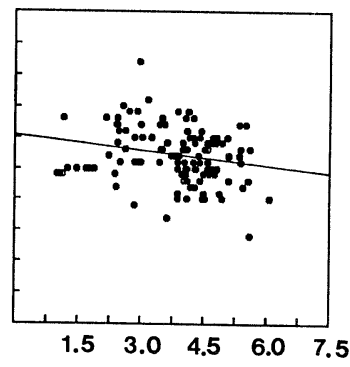

岩種 $d$

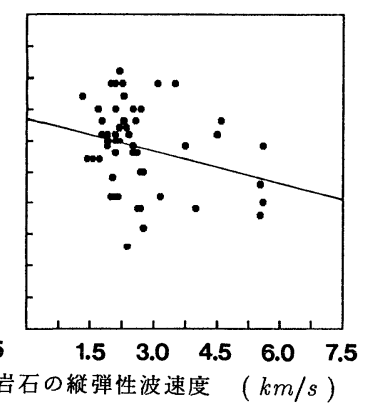

図一4 道路公団岩種の縦弾性波速度と各物性値間の関係 
表一5 道路公団岩盤分類についての物性値

\begin{tabular}{|c|c|c|c|c|c|c|}
\hline & 地山等級 & $\mathrm{A}$ & $\mathrm{B}$ & $\mathrm{C}$ & $\mathrm{DI}$ & DII \\
\hline \multirow{4}{*}{$\begin{array}{c}\text { 岩 } \\
\text { 種 }\end{array}$} & $\mathrm{Vp}$ & $V p>5.0$ & $5.0>V p>3.8$ & $3.8>V p>3.2$ & $3.2>V p>2.5$ & $2.5>V p$ \\
\cline { 2 - 8 } & 密度 & $\sim 2.70$ & $2.70 \sim 2.62$ & $2.62 \sim 2.56$ & $2.56 \sim 2.49$ & $2.49 \sim$ \\
\cline { 2 - 8 } & 一軸压縮強度 & $\sim 540$ & $540 \sim 239$ & $239 \sim 144$ & $144 \sim 69$ & $69 \sim$ \\
\cline { 2 - 7 } & 弾性係数 & $\sim 210$ & $210 \sim 77$ & $77 \sim 41$ & $41 \sim 16$ & $16 \sim$ \\
\cline { 2 - 7 } & \multirow{2}{*}{ ホン比 } & $\sim 0.26$ & $0.26 \sim 0.28$ & $0.28 \sim 0.30$ & $0.30 \sim 0.31$ & $0.31 \sim$ \\
\hline
\end{tabular}

\begin{tabular}{|c|c|c|c|c|c|c|}
\hline \multirow{5}{*}{$\begin{array}{l}\text { 種 } \\
\text { b }\end{array}$} & $V_{p}$ & $V p>5.0$ & $5.0>V p>3.8$ & $3.8>V p>3.2$ & $3.2>V p>2.5$ & $2.5>V p$ \\
\hline & 密度 & $\sim 2.67$ & $2.67 \sim 2.62$ & $2.62 \sim 2.59$ & $2.59 \sim 2.54$ & $2.54 \sim$ \\
\hline & 一軸压縮強度 & $\sim 1157$ & $1157 \sim 551$ & $551 \sim 347$ & $347 \sim 178$ & $178 \sim$ \\
\hline & 弾性係数 & $\sim 389$ & $389 \sim 208$ & $208 \sim 141$ & $141 \sim 80$ & $80 \sim$ \\
\hline & ポアソン比 & $\sim .0 .23$ & $0.23 \sim 0.24$ & $0.24 \sim 0.25$ & $0.25 \sim 0.26$ & $0.26 \sim$ \\
\hline
\end{tabular}

\begin{tabular}{|c|c|c|c|c|c|c|}
\hline \multirow{5}{*}{$\begin{array}{l}\text { 岩 } \text { 種 }\end{array}$} & $V_{p}$ & $V p>4.8$ & $4.8>V p>3.6$ & $3.6>V p>3.0$ & $3.0>V p>2.5$ & $2.5>V p$ \\
\hline & 密度 & $\sim 2.65$ & $2.65 \sim 2.58$ & $2.58 \sim 2.54$ & $2.54 \sim 2.49$ & $2.49 \sim$ \\
\hline & 一軸圧縮強度 & $\sim 1078$ & $1078 \sim 589$ & $589 \sim 401$ & $401 \sim 273$ & $273 \sim$ \\
\hline & 弾性係数 & $\sim 284$ & $284 \sim 151$ & $151 \sim 101$ & $101 \sim 68$ & $68 \sim$ \\
\hline & ポアソン比 & $\sim 0.263$ & $0.263 \sim 0.273$ & $0.273 \sim 0.278$ & $0.278 \sim 0.282$ & $0.282 \sim$ \\
\hline
\end{tabular}

\begin{tabular}{|c|c|c|c|c|c|c|}
\hline \multirow{5}{*}{$\begin{array}{l}\text { 岩 } \\
\text { 種 }\end{array}$} & $V_{p}$ & $V p>3.5$ & $3.5>V p>3.0$ & $3.0>V p>2.0$ & $2.0>V p>1.5$ & $1.5>V p$ \\
\hline & 密度 & $\sim 2.26$ & $2.26 \sim 2.20$ & $2.20 \sim 2.05$ & $2.05 \sim 1.95$ & $1.95 \sim$ \\
\hline & 一軸圧縮強度 & $\sim 365$ & $365 \sim 227$ & $227 \sim 65$ & $65 \sim 27$ & $27 \sim$ \\
\hline & 弾性係数 & $\sim 62$ & $62 \sim 42$ & $42 \sim 15$ & $15 \sim 7$ & $7 \sim$ \\
\hline & ポアソン比 & $\sim 0.27$ & $0.27 \sim 0.28$ & $0.28 \sim 0.30$ & $0.30 \sim 0.31$ & $0.31 \sim$ \\
\hline
\end{tabular}

\begin{tabular}{|l|}
\hline $\begin{array}{l}\text { 密度 }\left(\mathrm{g} / \mathrm{cm}^{3}\right), \text { 一軸圧縮強度 }\left(\mathrm{kg} / \mathrm{cm}^{2}\right) \\
\text { 弹性係数 } \times 10^{3}\left(\mathrm{kgf} / \mathrm{cm}^{2}\right)\end{array}$ \\
\hline
\end{tabular}

の段階で求まる岩盤の弾性波速度より, 断面における割 れ目指数を, 式 (4) 加求好. また, 岩石の弾性波 速度と岩種より, 表一5 から地山等級を決める. 道路公 団の岩盤分類においては, 岩盤の一軸圧縮強度は式 (6) から,つまり, 断面の割れ目指数を 2.7 乗した值を, 表 一 5 の地山等級と岩種の一致した項の一軸圧縮強度の值 に掛ければ推定できる. 同様に, 岩盤の弾性係数は, 式

（７）から推定できる. 亀裂のない岩石の弾性波速度が 測定できなければ，割れ目指数を仮定することで同様の ことができる.この方法は, 岩盤内に存在するクラック, 節理, 断層等の不確定要素をすべて, 割れ目指数の指数 乗の形に被いかぶせるため,さらに研究が必要であろう.

\section{7.おわりに}

NATM の設計のための物性值を岩盤データベースを 用いて推定するために, 岩石の弾性波速度についていろ いろ之考察した. その過程で以下の結果を得た.

（1）一軸圧縮強度は, 全デー夕に対して弾性波速度 の 2.7 乗に比例し, 弾性係数は同様に弾性波速度の 3.0 乗に比例する. 花崗岩については, この結果と異なった 挙動を示した. 弾性係数に対する相関係数は, 各岩石亡 も比較的高くなったが，一軸圧縮強度に対しての相関係 数は, 各岩石によってばらついた.

（2）密度に対しては, 各岩石の成因による特徵を示 したため, 特に砂岩では相関係数が高くなった。

（３）ポアソン比については, 弾性波速度に対して右 下がりの関係を得たが, 相関係数は高くない.
（４）岩石の弾性波速度と岩盤の弾性波速度との関係 については, 良好な相関関係が得られ, 岩石の弾性波速 度から, 岩盤の物性值を割れ目指数で推定できることを 示した。このデータベースに収納されているデー夕の平 均的な割れ目指数は 0.86 になった。

（5）岩盤の弾性係数と一軸圧縮強度は, 割れ目指数 を用いて式 (6) と（7）で推定できる.

（6）道路公団の岩盤分類の岩種について, 岩石の弾 性波速度と各物性值間の相関を求めたところ, 各岩石と 同様な比較的良い相関関係を得た。そこで各岩種ごとの 弾性波速度に対する物性值を示した，岩種ごとの岩盤の 弾性係数と一軸圧縮強度は, 割れ目指数を用いて同様に 式（6）と（7) から推定できる.

謝辞：本研究を遂行するにあたり「NATM の 設計・施工におけるエキスパートシステムの開発」委員 会の各委員に多大のご協力をいただいた。特に，(株) 熊 谷組, 御手洗良夫氏, 佐藤工業 (株) 篠川俊夫氏, 清水 建設 (株) 石塚与志雄氏, 大成建設 (株) 大坂 一氏, 西 松建設 (株) 北川 隆氏の各位には貴重なデー夕を提供 していただいた。ここに記して感謝の意を表する.

\section{参 考 文 献}

1）河田博之・朝倉俊弘：データベースとエキスパートシス テム, トンネルと地下, Vol.17, No. 12, pp. 27〜34, 1986.

2) 今津雅紀 : 岩盤物性のデータバンク化とトンネルへの適 用, 土と基礎, Vol. 35, No. 3, pp. 9 15, 1987.

3) Osaka, H., et al. : An expert system for tunnel design 
and tunnelling-TUX, IABSE Colloquium "Expert Systems in Civil Engineering”, Bergamo, Italy, October, 1989.

4）日本応用地質学会編：岩盤分類, 日本応用地質学会, 1984 .

5）日本道路公団：設計要領第三集第 9 編トンネル, pp. 32 ～36, 日本道路公団， 1985 .

6）日本国有鉄道：NATM 設計施工指針 (案), 1983.

7）農林省構造改善局 : 土地改良事業計画設計基準第三部設 計, 1975 .

8) Wickham, G. E., Tiedemann, H. R. and Skinner, E. H. : Support determinations based on geological predictions, North American Rapid Excavation and Tunnelling Conference, Chicago 1972, Proceedings, Vol.1, pp. 43 $\sim 64,1972$.

9) Bieniawski, Z.H. : Geomechanics Classification of Rock Masses and Its Application in Tunnelling, Proc. 3rd Int. Congress on Rock Mechanics, Vol.2, Part A, pp. 27 32, 1974.

10) Barton, N., Lien, R. and Lunde, J. : Engineering Classification of Rock Masses for the Design of Tunnel Support, Rock Mechanics, Vol.6, No.4, pp. 189 236, 1974.
11）清水則一・桜井春輔：ファジー理論を用いた岩盤分類の 構成方法に関する研究, 土木学会論文集, 第 370 号 / III -5, pp. 225 232, 1986.

12）岩田龍典・藤田修一・北條 明：トンネル掘削工事にお ける岩盤分類法の一考察，電力土木, No. 217, 1988.

13）㯪木 武・平田登基男・西頭道彦・相川 明：NATM の 数値解析のための地山分類と地山定数, 土と基礎, Vol. 34, No. 2, 1986.

14）池田和彦：トンネル岩盤分類に関する一考察，鉄道技術 研究報告, No.695, pp.1 31，1969.

15）日本鉱業会岩石試験データシート作成・利用研究委員会, 岩石試験データシートの作成と利用の現況，日本鉱業会 誌, Vol. 86, No. 8, pp. 507 552, 1986.

16）大久保彪-寺崎 晃：岩石の物理的性質と弾性波速度, 土と基礎，No.631，July, 1971.

17）井上正康 $\cdot$ 大見美智人：岩石供試体の縦波伝播速度と一 軸圧縮強度との関係, 応用地質, Vol.12, No. 3, 1971.

18) Kikuchi, K., Saito, K. and Kusunoki, K. : Geotechnically Intergrated Evalution on the Stability of Dam Foundation Rocks, Commission Internationale des Grands Barrages, Rio de Janeiro, 1982.

(1990.2.26 • 受付) 